\title{
SAVANNA FIRES AND THEIR IMPACT ON NET ECOSYSTEM PRODUCTIVITY
}

\author{
JASON BERINGER ${ }^{1}$, LINDSAY HUTLEY ${ }^{2}$ AND NIGEL TAPPER ${ }^{1}$ \\ ${ }^{1}$ School of Geography and Environmental Science, Monash University, Vic, 3800, AUSTRALIA \\ ${ }^{2}$ Faculty of Education, Health \& Science, Charles Darwin University, Darwin, NT, 0909, AUSTRALIA
}

\section{Introduction}

The role of fire as one of the primary natural carbon cycling mechanisms is a key issue in considering global climate change feedbacks. The combustion of the world's tropical savannas through biomass burning is a major source of global greenhouse gas emissions (Levine et al. 1995; Achard et al. 2004). In Australian tropical savannas, fire is the greatest natural and anthropogenic environmental disturbance, with vast tracts burnt each year. In order to understand the long-term carbon balance of these ecosystems we need to understand the impact of frequent burning. The term Net Biome Productivity (NBP) is applied to the net ecosystem carbon balance that incorporates the effect of disturbance (Schulze et al. 1999) and represents a more complete and long-term understanding of ecosystem function.

While ecological impacts of fire on the world's tropical savannas are relatively well understood (Yibarbuk et al. 2001; Williams et al. 2003; Williams et al. 2003), the effects on the physical environment and carbon balance are less well understood.

Previously, there has been an extensive suite of ecological (Bowman 1996), eco-physiological and flux measurements (Beringer et al. 2003) conducted at Howard Springs and similar sites in the Gunn Point region. Measurements have been made of vegetation structure and above-ground biomass (O'Grady et al. 2000), patterns of tree transpiration (O'Grady et al. 1999; Hutley et al. 2000), evapotranspiration (Hutley et al. 2000), soil water dynamics, catchment water balance (Cook et al. 1998), $\mathrm{CO}_{2}$ exchange (Eamus et al. 2001; Chen et al. 2002), and carbon balance (Chen et al. 2003).

The impacts of fire on the surface radiation and energy balance of Australian savannas has only recently been investigated. Beringer et al. (2003) documented large changes in surface properties of savannas resulting from burning, which included a halving of surface albedo (0.12 to 0.06 ), a doubling of canopy resistance, an increase in surface

\footnotetext{
${ }^{1}$ Corresponding author address : Jason Beringer, School of Geography and Environmental Science, Monash University, Melbourne, Australia, 3800. e-mail: jason.beringer@arts.monash.edu.au
}

roughness and a resulting decreased evapotranspiration and increased sensible heat flux to the atmosphere. However, the impact of fire on the $\mathrm{CO}_{2}$ fluxes and budget have not been previously quantified.

The direct impact of fire on the carbon balance includes the carbon emissions from burning of the grassy understorey. In 1992 it was estimated that $74,000 \mathrm{~km}^{2}$ of the Northern Territory burnt that in turn consumed an estimated $29.5 \times 10^{6}$ tonnes of biomass, and was associated with a likely release of more than $13 \mathrm{Tg}$ of carbon products to the atmosphere (Beringer et al. 1995). The indirect effect of burning on the ecosystem is to reduce the productivity following canopy scorching, leaf drop from the trees and subsequent recovery of the canopy. This magnitude of this reduction is difficult to estimate, however, it could be similar to the direct emissions from burning. Clearly the impact of fire in these ecosystems is large and assume even greater significance given predictions of increases of up to $30 \%$ in seasonal cumulative fire danger in parts of northern Australia under predicted climate change due to increased greenhouse gas emissions (Williams et al. 2001). It should be noted that carbon cycling is very rapid in these frequently disturbed ecosystems.

Here we present results examining the effect of fire on the exchanges of carbon dioxide from a northern Australian tropical savanna. We measured fluxes of heat, moisture and carbon dioxide over typical tropical savanna using the eddy covariance technique (Baldocchi et al. 1988) over a two year period. Simultaneous measurements of burned and unburned savanna were collected. We present data to examine the year to year variability and attempt to estimate the Net Biome Productivity (NBP) of our site.

\section{Methods}

\subsection{Study Site}

Measurements were made in the Howard River catchment $\left(12^{\circ} 29.712^{\prime} \mathrm{S} / 131^{\circ} 09.003^{\prime} \mathrm{E}\right)$, located on the Gunn Point peninsula, $35 \mathrm{~km}$ south east of Darwin, Northern Territory. The vegetation of the catchment and region is a mosaic of Eucalypt dominated woodland and open-forest savanna, 
closed forests, seasonally flooded swamps and wetlands. All measurements were made in openforest savanna (Wilson et al. 1990) which is the most dominant vegetation type. Vegetation, soils and climate of this site have been previously described by O'Grady et al. (2000), Hutley et al. (2000) and Hutley et al. (2001). Soils at the site are red earth sands (red Kandosols, after (Isbell 1996) with an overstorey dominated (in terms of leaf area and biomass) by two Eucalypt species, Eucalyptus tetrodonta (F. Muell.) and E. miniata (Cunn. Ex Schauer). These and other tree species form a canopy of between 14-15 $\mathrm{m}$ in height, with overstorey LAI ranging from 0.95 to 0.6 between the wet and dry seasons (O'Grady et al. 2000). The understorey consists of semi-deciduous and deciduous small trees and shrubs, but is dominated by the tall, C4 annual grass, Sorghum spp. Understorey LAI is maximal between February and March and reaches 1.2-1.5 and rapidly declines to 0.2 with the onset of the dry season in April and May. This site is representative of frequently burnt, mesic savannas of the coastal regions of the Northern Territory, occupying an area of some 135 $000 \mathrm{~km}^{2}$ and occurring above the $1200 \mathrm{~mm}$ rainfall isohyet (Wilson et al. 1990). This and other closely associated Eucalypt dominated savanna types also occur in north-western Western Australia and the Gulf of Carpentaria region of northern Queensland and occupy up to $200000 \mathrm{~km}^{2}$ in northern Australia (Fox et al. 2001).

\subsection{Flux measurements}

In this study, a permanent flux tower was instrumented in August 2001. We present data from the two years ending July 2003. The site has been subjected to a moderate intensity fire each year during the study, which is representative of the regional fire return time of 2 years burned out of every 3.

The site was a E. tetrodonta / E. miniata openforest savanna and had adequate homogeneous fetch in all directions $(>1 \mathrm{~km})$ with slopes of $<1^{\circ}$.

Fluxes of heat, moisture and $\mathrm{CO}_{2}$ were measured using the eddy covariance technique and is detailed for the site by Beringer et al. (2003). The radiation balance was measured using incoming and reflected shortwave and incoming and emitted long-wave radiation, along with an independent measurement of net radiation.

A continuous half-hourly data set over two years was constructed. A neural network strategy was employed to gap fill flux data during times where measurements were invalid or missing using Statistica (Statsoft, USA). Climate and radiation data were taken from the nearby Darwin airport when data were missing from the tower.

Net $\mathrm{CO}_{2}$ fluxes $\left(\mathrm{F}_{\mathrm{c}}\right)$ were measured directly using the eddy covariance approach and accounted for storage in the canopy (between the ground and $18 \mathrm{~m})$. Data were $u^{*}$ corrected using a threshold value of 0.2 (Baldocchi et al. 2000). At night-time when $u^{*}$ values exceeded $0.2, F_{c}$ was taken to be equal to the total ecosystem respiration $\left(R_{e}\right)$. Neural networking was used to develop a relationship between $R_{e}$ and soil temperature and moisture data for the two years of data. This relationship was then applied to night-time data (where $u^{*}$ values were $<0.2$ ) and all the daytime data. During daylight hours the Gross Primary Production (GPP) was taken to be $F_{c}-R_{e}$. An example 10-day period is shown in Figure 1 .

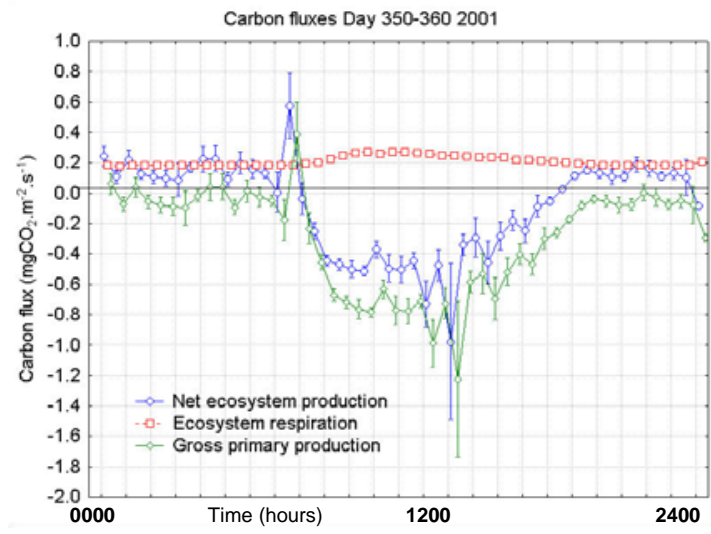

Figure 1. Measured $F_{c}$ and calculated component fluxes for a typical 10-day period during the wet season of 2001.

Observations of energy and moisture exchange were made in conjunction with vegetation biomass and structure, fuel loads and fire intensities. Measurements were taken between July 2001 (dry season) and July 2003. The time system used here is local Central Standard Time (CST), which is (UTC +9.5 Hours). Throughout this paper the term daily refers to the 24-hour period from midnight to midnight and daytime refers to the period when net radiation is positive (10:00-18:00). Solar noon at Howard Springs was close to 13:00 CST.

\subsection{Fire measurements}

Fire occurred during each dry season at the site. Fire intensity at each site was based on the relationship of Williams et al. (1997) using char and scorch heights. The details of each fire are given in Table 1. 
Table 1. Fire intensity and fuel loads for fires during the measurement period.

\begin{tabular}{|l|l|l|}
\hline & $\begin{array}{l}\text { Dry Season } \\
\text { 2001 }\end{array}$ & $\begin{array}{l}\text { Dry Season } \\
\mathbf{2 0 0 2}\end{array}$ \\
\hline Date & $\begin{array}{l}\text { day 218 (6 } \\
\text { Aug ) }\end{array}$ & $\begin{array}{l}\text { Day 230 }\left(18^{\text {th }}\right. \\
\text { Aug) }\end{array}$ \\
\hline $\begin{array}{l}\text { Average } \\
\text { intensity (kW } \\
\left.\mathbf{m}^{-1}\right)\end{array}$ & $3550 \pm 640$ & $\sim 3000$ \\
\hline $\begin{array}{l}\text { Grassy fuel } \\
\text { load (t ha }\end{array}$ & $1.58 \pm 0.18$ & $2.9 \pm 0.26$ \\
\hline
\end{tabular}

\section{Results and discussion}

Previous estimates of the carbon balance in tropical Australian savannas (Eamus et al. 2001; Chen et al. 2003) have not considered the impact of fire, despite the almost annual burning of the savanna ecosystems. In order to determine the Net Biome Productivity (NBP) we need to account for the impact of fire. The ecosystem will be affected in two ways;

1. The direct emissions from the burning of fuel and loss of carbon to the atmosphere.

2. The impact on ecosystem productivity following fire.

The direct emissions are easily quantified by measuring fuel loads and combustion efficiencies (Table 1). Here we concentrate on the impact on ecosystem productivity and the subsequent recovery over time and we use the fire of 2001 (Table 1) as an example.

\subsection{Short-term ecosystem recovery}

Crown fires are rare in these savanna ecosystems, due to a fire regime characterised by frequent, low intensity fires (Williams et al. 1998). However, heat from the understorey during a moderate intensity fire (ca. $3000-5000 \mathrm{kWm}^{-1}$ ) causes substantial canopy scorch and subsequent leaf fall from the dominant trees in the weeks following fire. Such canopy damage can dramatically reduce transpiration and fundamentally change the ratio of energy partitioning, including albedo (Beringer et al. 2003).

During the dry season burn of 2001 the impact on the canopy is seen in the calculated values of canopy resistance. Canopy resistance increases over two-fold following fire and almost immediate leaf drop (Figure 2). The post burn period is evident for around 4-5 weeks after which the canopy flushes with new leaves. This recovery is evident by the decreasing canopy resistance to pre burn levels, which occurs around 6 weeks after fire. This was consistent with observations of canopy flushing. At this time transpiration had resumed. It should be noted that during this entire period there was no rainfall until day 275 (Figure 2).

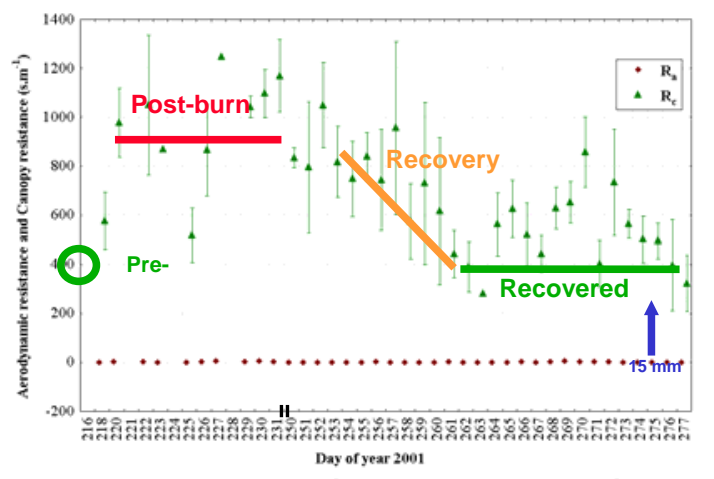

Figure 2. The aerodynamic and canopy resistance before and after fire during 2001. The phases of recovery are shown along with the only rainfall for the period (15mm).

Even though the canopy recovered rapidly over a six week period the ecosystem carbon balance did not. There was a reversal of carbon fluxes from a sink of around $-1.3 \mathrm{gC} \cdot \mathrm{m}^{-2}$. day ${ }^{-1}$ before the fire to a source of $+1.5 \mathrm{gC} . \mathrm{m}^{-2}$ day $^{-1}$ following fire (Figure 3).

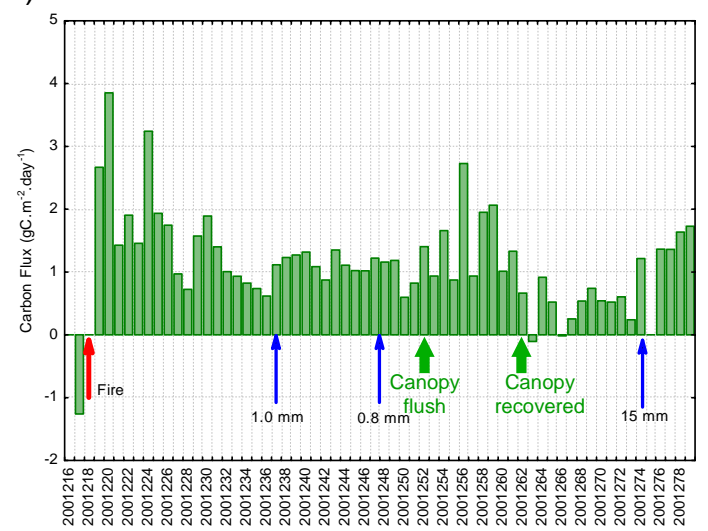

Figure 3. The savanna changes from sink to source after fire and remains a source despite canopy recovery.

Despite the recovery of the canopy and resumed transpiration by day 262 , the ecosystem remained a moderate source to the atmosphere (1 $\mathrm{gC} \cdot \mathrm{m}^{-2} \cdot$ day $\left.^{-1}\right)$. Soil conditions were virtually identical throughout the period. A possible explanation is that there is a high maintenance cost of rebuilding the canopy and that even though the canopy is photosynthesising that there is an overwhelmingly high autotrophic respiration associated with the reallocation of stored carbon (presumably from lignotubers) to new leaves. In any case, the indirect impact of fire is to reduce the productivity of the ecosystem for several months as the canopy is rebuilt and recovers. This is loss of 
productivity adds to that already lost directly from the ecosystem through the combustion of the grass understorey.

\subsection{Longer-term recovery following fire}

The ecosystem appears to slowly return to a carbon sink and given the rate of recovery of carbon fluxes during the six weeks following fire, it could potentially take up to 16 weeks to reach preburn levels. It is however difficult to determine the exact duration because the wet season commences at around Julian day 274 with the first substantial rains $(15 \mathrm{~mm})$ (Figure 4$)$. These savanna ecosystems are highly dynamic and respond to the seasonal wet/dry nature of the climate. Following the first rains the ecosystem becomes a strong source of $\mathrm{CO}_{2}$ to the atmosphere. This is likely associated with dramatically increased soil respiration after the prolonged dry season, a typical birch type effect (Birch 1958).

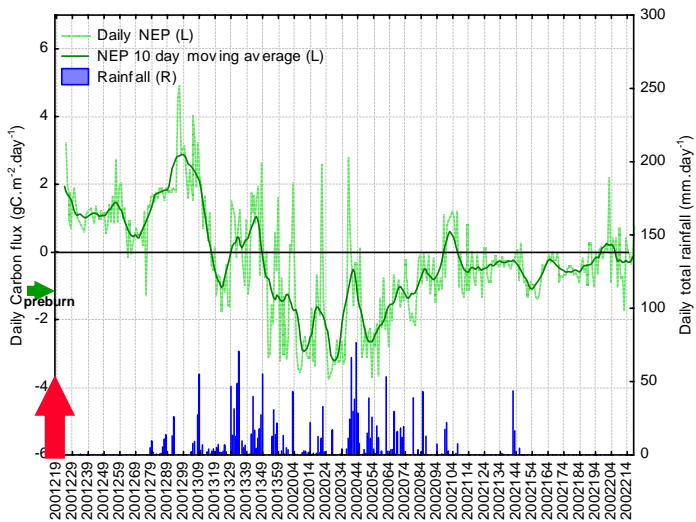

Figure 4. The annual course of daily carbon fluxes (NEP) at the site from August 2001 to July 2002 (individual days and a 10-day moving average are shown). The large arrow shows the timing of the fire in 2001 along with preburn average daily sink of -1.3 gC. $\mathrm{m}^{-2}$ day ${ }^{-1}$. Daily rainfall totals are shown as vertical bars.

The grasses germinated at the commencement of the wet season (around Dec) after approximately $50 \mathrm{~mm}$ of accumulated rainfall. Once established the ecosystem reached its maximum daily uptake $\left(\sim 3 \mathrm{gC}^{-2} \mathrm{day}^{-1}\right.$ in 2001) (Figure 4). Once the wet season finished the grasses rapidly senesced and the ecosystem productivity was dominated by tree productivity.

\subsection{Annual ecosystem productivity.}

The Net Ecosystem Production (NEP) has been previously estimated by Eamus et al. (2001) using campaign based eddy covariance measurements site as $-2.8 \mathrm{tC} \cdot \mathrm{ha}^{-1} \mathrm{y}^{-1}$, during a year without fire.

Our annual NEP values exclude the direct emissions from burning but do include the indirect effects of loss of ecosystem production following fire and the subsequent recovery. These values were -0.7 and -2.6 tC. ha $^{-1} \mathrm{y}^{-1}$ for 2001-2002 and 2002-2003 respectively (Figure 5).

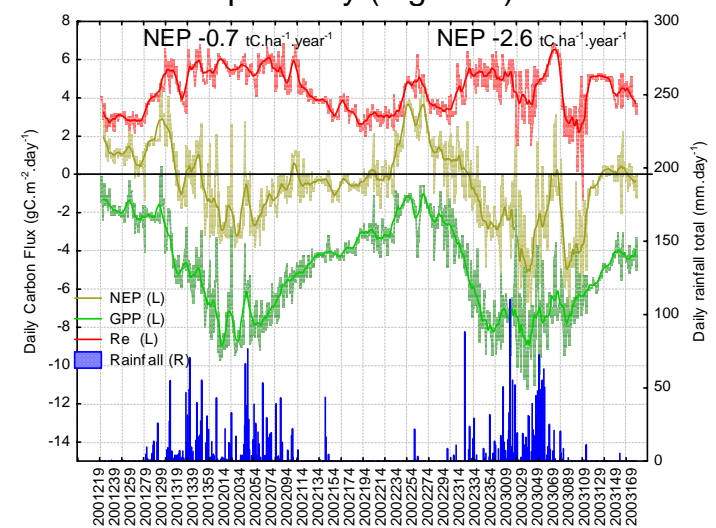

Figure 5. The daily net $\mathrm{CO}_{2}$ flux and the components of Re and GPP for the two year period 2001-2003. Annual NEP values are also shown for each year.

The large increase in NEP for 2002-2003 is partly due to lower annual ecosystem respiration but mostly due to increased GPP (Table 3). To investigate the source of the increased GPP we decomposed the total GPP into the tree and grass components. We assumed that during the dry season, when grasses have senesced, that the daily GPP is entirely from the trees. We then developed a neural network model (based on light, moisture, VPD, and air temperature) to calculate the tree GPP through into the wet season. We took the grass GPP to be the difference between the total GPP and tree GPP (Figure 6).

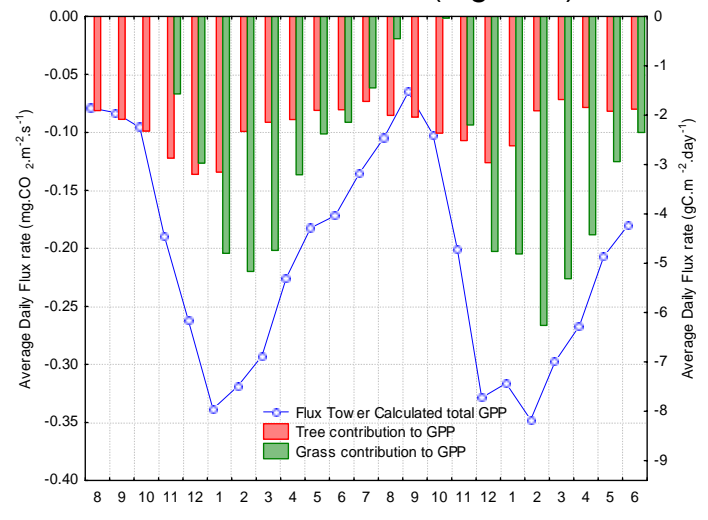

Figure 6. The monthly contribution of tree and grass GPP over the two year period, calculated using neural networking. 
This analysis showed that the increased GPP comes predominantly from the grass understorey and that tree GPP was invariant from year to year. This is consistent with an observed doubling of the grassy fuel load (Table 1).

Table 2. The contribution of tree and grass GPP to total GPP.

\begin{tabular}{|c|c|c|}
\hline YEAR & $\begin{array}{l}\text { TREES } \\
\left(\mathrm{tC} \cdot \mathrm{ha}^{-1} \cdot \mathrm{yr}^{-1}\right)\end{array}$ & $\begin{array}{l}\text { GRASS (tC.ha } \\
\left.1 . \mathrm{yr}^{-1}\right)\end{array}$ \\
\hline 2001-2002 & -8.6 & -8.5 \\
\hline $2002-2003$ & -8.5 & -10.2 \\
\hline
\end{tabular}

\section{c. Net Biome Productivity (NBP)}

The annual NEP values cited above do not account for the direct emissions of carbon from biomass burning. We have measured the understorey fuel loads and calculated the losses due to fire based on a combustion efficiency of 0.72 (ratio of fuel pyrolised to fuel load within areas over which flames have passed) ( Russell-Smith et al. 2003). The emissions were calculated as +1.5 and +2.9 tC. ha $^{-1}$. year $^{-1}$ for the years 2001-2002 and 2002-2003 respectively. Hence the true NEP values, including the effect of fire for one year, are +0.8 and +0.3 tC. $^{-1}$. $^{-1}$ ear $^{-1}$ (Table 3). Therefore this savanna system is a small source on an annual basis.

Table 3. Estimate of NBP for this savanna site based on two years of measured data including fire (this study) and one year of previous measurements excluding fire.

\begin{tabular}{|l|l|l|l|}
\hline & $2001-2002$ & $2002-2003$ & $\begin{array}{l}\text { (Eamus et } \\
\text { al. 2001) }\end{array}$ \\
\hline$R_{e}$ & +16.1 & +15.6 & \\
\hline GPP & -16.8 & -18.0 & \\
\hline NEP & -0.7 & -2.6 & $-2.8^{A}$ \\
\hline Fire losses & +1.5 & +2.9 & \\
\hline NEP-fire & $+0.8^{A}$ & $+0.3^{A}$ & \\
\hline NBP & Average of values & \\
\hline
\end{tabular}

However, this is not the true NBP as we must take into account the frequency of disturbance. At our site the system is burned 2 out of every 3 years. Our study has documented two years that included fire and with an additional year of data with no burning we should be able to estimate the NBP. Previous measurements by Eamus et al. (2001) represent a year where burning was absent

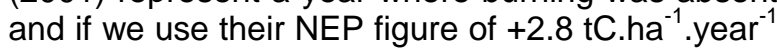
then we can make a coarse estimate the NBP of this savanna site as -0.6 tC. $^{-1}$. $^{-1}$ ear $^{-1}$ (Table 3).

\section{Conclusions}

The NEP of the site including the losses from burning were +0.8 and +0.3 tC. $^{-1}$. $^{-1 e a r}{ }^{-1}$ for 20012002 and 2002-2003 respectively, indicating that in years with fire that the ecosystem is a net source to the atmosphere. Over longer periods the NBP was estimated at +0.6 tC. $^{-1} \mathrm{~h}^{-1}$ year $^{-1}$. This small sink suggests that the ecosystem is close to carbon neutral with losses due to fire being regained through photosynthesis in the following year, particularly grass GPP. Despite a vegetative return to pre fire conditions the net flux on a global basis has been estimated at 280-460 ( $\mathrm{Tg} \mathrm{dm} / \mathrm{yr})$ based on 340-560 ( $\mathrm{Tg} \mathrm{dm} / \mathrm{yr}$ ) of cleared biomass and 60100 (Tg dm/yr) of regrowth (Seiler and Crutzen 1980). In contrast, enhanced biomass productivity of 30 to $60 \%$ after burning has been observed in some humid savanna studies (San Jose and Medina 1975).

It will be important to model the long term carbon dynamics in order to investigate the influence of fire frequency on savanna carbon budgets. As far as savanna management is concerned there may be potential for increasing carbon storage in ecosystems by reducing fire frequency (Sohngen and Haynes 1997). Uncertainties in the estimates of NBP include factors such as the storage of elemental carbon in charcoal through burning and the decomposition of unburned above and below ground biomass (Seiler and Crutzen 1980) along with burning practices and timing. There remains considerable uncertainty in these long term carbon balance estimates.

\section{Acknowledgements}

This work was funded by the Australian Research Council (DP0344744). We would like to thank the following postgraduate students for their assistance (Chris Wendt, Andrew Coutts, Andrew Kerley, and Chloe Tame).

\section{References}

Achard, F., H. D. Eva, P. Mayaux, H. J. Stibig and A. Belward (2004). "Improved estimates of net carbon emissions from land cover change in the tropics for the 1990s - art. no. GB2008." Global Biogeochemical Cycles 18(2): B2008-B2008.

Baldocchi, D., J. Finnigan, K. Wilson, K. T. Paw U and E. Falge (2000). "On measuring net ecosystem carbon exchange over tall vegetation on complex terrain." Boundary-Layer Meteorology 96(1-2): 257-291. 
Baldocchi, D. D., B. B. Hicks and T. P. Meyers (1988). "Measuring biosphere-atmosphere exchanges of biologically related gases with micometeorological methods." Ecology 69(5): 1331-1340.

Beringer, J., L. B. Hutley, N. J. Tapper, A. Coutts, A. Kerley and A. P. O'Grady (2003). "Fire impacts on surface heat, moisture and carbon fluxes from a tropical savanna in north Australia." International Journal of Wildland Fire 12: 333-340.

Beringer, J., D. Packham and N. J. Tapper (1995). "Biomass burning and resulting emissions in the Northern Territory, Australia." International Journal of Wildland Fire 5(4): 229-235.

Birch, H. F. (1958). "The effect of soil drying on humus decomposition and nitrogen availability." Plant and Soil 10: 9-31.

Bowman, D. (1996). "Diversity Patterns of Woody Species on a Latitudinal Transect from the Monsoon Tropics to Desert in the Northern Territory, Australia." Australian Journal of Botany 44(5): 571580.

Chen, X. Y., D. Eamus and L. B. Hutley (2002). "Seasonal patterns of soil carbon dioxide efflux from a wet-dry tropical savanna of northern Australia (vol 50, pg 43, 2002)." Australian Journal of Botany 50(3): 373-NIL_20.

Chen, X. Y., L. B. Hutley and D. Eamus (2003). "Carbon balance of a tropical savanna of northern Australia." Oecologia 137(3): 405-416

Cook, P. G., T. J. Hatton, D. Pidsley, A. L. Herczeg, A. Held, A. O'Grady and D. Eamus (1998). "Water balance of a tropical woodland ecosystem, Northern Australia: a combination of micro-meteorological, soil physical and groundwater chemical approaches." Journal of Hydrology 210(1-4): 161 177.

Eamus, D., L. B. Hutley and A. P. O'Grady (2001). "Daily and seasonal patterns of carbon and water fluxes above a north Australian savanna." Tree Physiology 21(12-13): 977-988.

Fox, I. D., V. J. Neldner, G. W. Wilson, P. J. Bannink, B. A. Wilson, P. S. Brocklehurst, M. J. Clark, K. J. M Dickinson, J. S. Beard, A. J. M. Hopkins, G. R. Beeston, J. M. Harvey, E. J. Thompson, T. S. Ryan, S. L. Thompson, D. W. Butler, H. Cartan, E. P. Addicott, L. P. Bailey, R. J. Cumming, D. C. Johnson, M. Schmeider, K. M. Stephens and A. R. Bean (2001). The Vegetation of the Australian Tropical Savannas. Brisbane, Environmental Protection Agency.

Hutley, L. B., A. P. O'Grady and D. Eamus (2000). "Evapotranspiration from eucalypt open-forest savanna of northern Australia." Functional Ecology 14(2): 183-194.

Hutley, L. B., A. P. O'Grady and D. Eamus (2001). "Monsoonal influences on evapotranspiration of savanna vegetation of northern Australia." Oecologia 126(3): 434-443.

Isbell, R. F. (1996). Australian Soil Classification. Melbourne, CSIRO Publishing.

Levine, J. S., W. R. Cofer III, D. R. J. Cahoon and E. L. Winstead (1995). "Biomass burning: A driver for global change." Environmental Science and Technology 29(3): 120A-125A.

O'Grady, A. P., X. Chen, D. Eamus and L. B. Hutley (2000). "Composition, leaf area index and standing biomass of eucalypt open forests near Darwin in the Northern Territory, Australia." Australian Journal of Botany 48(5): 629-638.

O'Grady, A. P., D. Eamus and L. B. Hutley (1999). "Transpiration increases during the dry season: patterns of tree water use in eucalypt open-forests of northern Australia." Tree Physiology 19: 591-597.

Russell-Smith, J., A. C. Edwards and G. D. Cook (2003). "Reliability of biomass burning estimates from savanna fires: Biomass burning in northern Australia during the 1999 Biomass Burning and Lightning Experiment B field campaign - art. no. 8405." Journal of Geophysical Research-Atmospheres 108(D3): 8405-8405.

San Jose, J. J. and E. Medina (1975). Tropical Ecological Systems, Ecological studies, Volume 11. F. B. Golley and E. Medina. Berlin, Springer-Verlag: 251-264.

Schulze, E.-D., J. Lloyd, F. M. Kelliher, C. Wirth, C. Rebmann, B. Luhker, M. Mund, A. Knhol, I. M. Milyukova, W. Schulze, W. Ziegler, A. B. Varlagin, A. F. Sogachev, R. Valentini, S. Dore, S. Grigoriev, O. Kolle, M. I. Panfyorov, N. Tchebakova and N. N. Vygodskaya (1999). "Productivity of forests in the Eurosiberian boreal region and their potential to act as a carbon sink - a synthesis." Global Change Biology 5: 703-722.

Seiler, W. and J. Crutzen (1980). "Estimates of gross and net fluxes of carbon between the biosphere and the atmosphere from biomass burning." Climatic Change 2(3): 207-247.

Sohngen, B. L. and R. W. Haynes (1997). "The potential for increasing carbon storage in United States unreserved timberlands by reducing forest fire frequency: An economic and ecological analysis." Climatic Change 35: 179-197.

Williams, A. A. J., D. J. Karoly and N. Tapper (2001). "The sensitivity of Australian fire danger to climate change." Climatic Change 49: 171-191.

Williams, P. R., R. A. Congdon, A. C. Grice and P. J. Clarke (2003). "Effect of fire regime on plant abundance in a tropical eucalypt savanna of northeastern Australia." Austral Ecology 28(3): 327-338.

Williams RJ, Griffiths AD, Allan G (2002) Fire regimes and biodiversity in the wet-dry tropical savanna landscapes of northern Australia. pp281-304 In 'Flammable Australia: The Fire Regimes and Biodiversity of a Continent' (Eds RA Bradstock, JA Williams and AM Gill). (Cambridge University Press: Cambridge).

Williams, R. J., A. M. Gill and P. H. R. Moore (1998). "Seasonal changes in fire behaviour in a tropical Savanna in Northern Australia." International Journal of Wildland Fire 8(4): 227-239.

Williams, R. J., B. A. Myers, W. J. Muller, G. A. Duff and D. Eamus (1997). "Leaf phenology of woody species in a North Australian tropical savanna." Ecology 78(8): 2542-2558. 
Williams, R. J., J. C. Z. Woinarski and A. N. Andersen (2003). "Fire experiments in northern Australia: contributions to ecological understanding and biodiversity conservation in tropical savannas." International Journal of Wildland Fire 12(3-4): 391402.

Wilson, B. A., P. S. Brocklehurst, M. J. Clark and K. L. M. Dickinson (1990). Vegetation survey of the Northern Territory, Australia. Technical report No. 49. Darwin, Conservation Commission of the Northern Territory.

Yibarbuk, D., P. J. Whitehead, J. Russell-Smith, D. Jackson, C. Godjuwa, A. Fisher, P. Cooke, D.

Choquenot and D. Bowman (2001). "Fire ecology and Aboriginal land management in central Arnhem Land, northern Australia: a tradition of ecosystem management." Journal of Biogeography 28(3): 325343. 